\title{
throwing the book versus. cutting some slack: factors influencing the use of discretion by game wardens in kentucky
}

\author{
Stephen L. Eliason \\ Morehead State University, Morehead, \\ Kentucky, USA
}

While many studies have been done on urban' police officers, very little research has been directed toward the study of rural and specialized law: enforcement personnel. This paper provides a descriptive and exploratory account of factors associated with the use of discretion by a type of specialized, rural law enforcement officer: the game warden. Using qualitative data obtained from open-ended questions in a mail survey as well as in-depth interviews with 24 game wardens in the state of Kentucky, legal and extralegal factors that influence patterns of discretion are described. The extent of prior wildlife related deviance committed by game wardens themselves as youths also was examined. The data revealed widespread use of discretion by game wardens, with factors such as seriousness of the offense, prior contact with wardens, reputation as a violator; and intent of the offender playing key roles in terms of influencing. patterns of officer discretion.

Rèceived 14 September. 2001; accepted 5 April 2002.

This research was funded by the Research and Creative Productions Committee and the Institute for Regional Analysis and Public Policy (IRAPP) at Morehead State University. The author thanks the anonymous reviewers for their helpful comments.

Address correspondence to Stephen L. Eliason, Department of Sociology, Social Work and Criminology, Morehead State University, Morehead, KY 40351. E-mail: s.eliason@ moreheadstate.edu 


\section{INTRODUCTION}

The fact that rural crime has generally been neglected by social scientists is well documented (Bachman 1992; Gibbons 1972; Weisheit and Wells 1996). Because of the perception held by many scholars that crime is a product of cities and urbanization, sociological and criminological research has been heavily biased toward the study of urban: crime. Weisheit and Wells (1996:379) claim that this has resulted in "urban ethnocentrism," which is characterized"by a tendency of scholars to develop methods and theories "for urban crime problems and then to assume that they have universal application." *

However, it is important to keep in mind the fact that crime does exist in rural areas, and that much of it takes thẹ form of violations of hunting and fishing statutes (Gibbons 1972; Hummel 1983). Gibbons (1972:178) states "Although 'chumming' for fish, hunting without-a license, poaching deer, and so forth are not what citizens usually have in mind when they talk about the 'crime problem,' this activity is a. significant form of lawbreaking. "The illegal taking of wildlife resources, or poaching, has also received scant attention from social scientists (Eliason 1999; Eliason and Dodder 1999; Muth and Bowe 1998).

Game wardens or conservation " officers" are the làw enforcement personnel who are specifically entrusted to enforce state and federal fish and wildlife. regulations. The forerunner of the modern day game warden originated in Europe, and was called. the "gamekeeper" (Palmer and Bryant. 1985). Studies suggest that these individuals were typically former poachers who were chosen on the maxim:"set a thief to catch a thief" (Kirby 1933; Munsche 1981; Stockdale 1993):

While a considerable number of studies háve been directed toward the study of urban police officeris, very little sociological research has been done on rural law enforcement officers, including those who enforce fish and wildife laws (Forsyth 1993a; Forsyth 1993b; Palmer and Bryant 1985). Bryant, Shoemaker, Skipper, and Snizek (1985:107) point out that while studies of urban police officers abound "the investigation of specialized law enforcement agencies is rare."

Part of the reason for a lack of research on game wardens may be due to perceptions about the type of offenses game wardens deal with. Game wardens are the formal social control agents who are specifically designated to enforce wildlife statutes. Their primary role is to monitor hunting and fishing activities and to cite those who violate wildlife laws. However, hunting and fishing offenses are often viewed as "folk crimes" (Ross 1961). These are defined as "criminal acts ... which fail to seriously violate public sentiments, either within the subculture in which they take place or within society at large" (Muth 1998:5). Thus, in the eyes of the public as well as many scholars, the offenses game wardens deal with tend to be viewed as trivial in nature when compared to those dealt with by other law enforcement agencies.

In reality, when compared with other law enforcement - officers, their job is a potentially dangerous one. Game wardens deal with some unique situations that are alien to their urban law enforcement counterparts, in that they generally work alone and in remote and isolated rural regions, they lack immediate back-up by fellow law enforcement officers, and they routinely deal with individuals that are armed and frequently intoxicated or high from alcohol or drugs (Palmer and Bryant 1985; Walsh and Dónovan 1984). Garne wardens are sometimes physically assaulted and even killed while attempting to enforce wildlife regulations (Baird 1983; Long 1985).

While their primary responsibility is the enforcement of wildlife and boating laws, they often encounter other law violations in the field, such as those involving drug laws, driving under the influence of alcohol, stolen property, individuals with outstanding warrants, and so on. They always need to exercise caution since the person whose license they are checking may have an outstanding warrant or be a parole violator who does not want to go to jail.

Despite the fact that many members of society have percèptions of law enforcement officers as fine, upstanding members of the community, previous research on the law enforcement occupation suggests that police officers routinely engage in various types of occupational related deviance. It occurs in the form of lying and entrapment (Barker and Carter 1990; Vago 2000), committing brutality against citizens (Barker and Carter 1986), and participating in various forms of 
graft and corruption including bribery and the acceptance of kickbacks (Coleman 1994;' Pfohi 1994).

One topic that has been identified as an area that warrants exploration is that of personal experiences of game wardens including deviance committed by conservation officers as youth-and its relationship with the use of discretion (Forsyth 1994). Few studies have examined deviance committed by law enforcement personnel during their youth and prior to becoming sworn officers. The possibility has been raised that officers who have engaged in certain types of devianice in the past may be inclined to be more lenient toward individuals they apprehend who are engaged in similar types of deviance.

Discretion is an area that has received a fair amount of attention in the police literature. Officer discretion is an important aspect of the occupation for law enforcement officers (Black and Reiss 1970; Brown 1981; Gicourel. 1976; Pepinsky 1976; Skolnick 1975). Discretion refers to the ability to choose from two or more different courses of action to resolve a law enforcement situation. Police officers have the ability to arrest someone or to let them off with a formal , warning. They may also deal with violators informally by $\therefore$ :. giving them a verbal reprimand, or they can altogether ignore the illegal activity.

Legal as well as extralegal "factors have been found to influence the decisions of police officers when deciding how to dispose of offenses (Forsyth 1993b; Regoli and Hewitt 2000). One factor is the seriousness of the offense (Black and Reiss 1970; Skólnick -1975). Those who commit serious. crimes are more likely to be arrested than those who commit minor infractions. Another factor is the presence of a prior record (Cicourel 1976; Smith and. Visher 1981). Those who have been arrested previously or who have simply had a number of prior police contacts are more likely to be arrested than those with no prior police contacts. The attitude or demeanor of the offender also plays a role in the use of discretion (Becker 1963;- Piliavin and Briar 1964). Individuals that are uncooperative with and disrespectful- to the police are more"likely to be formally processed than those who are sincere and show genuine respect to the officer.

Other factors believed to influence the use of discretion - include age, socioeconomierstatus; and race... In terms of age, those who are very young as.well as those who are elderly are more likely to be treated leniently by the police than others (Forsyth and Shover 1986; Terry 1967). Individuals of lower socioeconomic status are more likely to be perceived as being involved in crime than middle and upper class individuals, and are more likely to be officially processed-by the police (Bartollas and Miller 2001). In terms of gender and race, the evidence suggests that females are more likely to be treated leniently than males, and that Blacks are more likely to be officially processed for offenses than are White individuals (Bartollas and Miller 2001).

Another factor that should be taken into consideration when dealing with the use of discretion, particularly in the case of wildife law enforcement, is intent. An individual who violates any wildlife law may be cited for it since these are considered "strict liability" offenses. In these situations" the officer simply has to show that an individual committed an act, and does not need to prove that they committed an act, however, it seems reasonable to presume intended to do some officers may exercise personal discretion and be lenient on an offender if they believe the offense was the result of an unintentional, honest mistake or due to genuine ignorance of the law rather.than a deliberate, intentional violation of the law.

Previous research on game wardens has examined factors such as their social profile and occupational activities (Palmer and Bryant 1985), discretion (Forsyth 1993b; Forsyth, Gramling and Wooddell 1998), policing styles: (Forsyth 1994); and the apprehension of poachers (Forsyth 1993a). The purpose of this study is to extend previous research on game wardens by this study is to extend previous research on game wardens use of discretion by them in the course of their occupation. Prior wildlife related deviance committed by game: wardens and its association with the use of discretion is examined as well.

\section{METHODOLOGY}

"This "study used qualitative data and employed the approach known as interpretive interactionism (Denzin 1989). It refers to "the attempt to make the world of problematic lived experience of ordinary people directly available 
to the reader. The interactionist interprets these worlds" (Denzin 1989:7). To this end, extensive quotes from game wardens are presented. This approach allows the participants to speak for themselves, and permits the essence of their world to be captured in full, vivid detail. Summarization and interpretation of their comments is provided by the author.

In terms of data collection, methodological triangulation was utilized (Denzin 1970). Data for this study was collected from a mail survey as well as in-depth interviews. In the first phase, of the project a survey was mailed to all current

$\because$ Kentucky Wild life and Boating Officers in April $2001(N=146)$. It contained a series of open-ended questions designed to gather information and reveal attitudes regarding the use of discretion, personal experiences of engaging in wildlife related deviance as youth, and background characteristics of the wardens (Dillman 1978). Open-ended questions were used so that the participants could respond in their own words,

$\because$ : thus presenting the job of game warden in vivid detail. A total - of 29 surveys: were completed and returned.

In -the second phase of the project, in-depth interviews were conducted with game wardens who returned the survey and agreed to be interviewed. A question was placed on the survey asking them if they would consent to a telephone interview, and if so to provide their phone number. A total of 24 in-depth interviews were conducted with game wardens between April and June of 2001. Interviews ranged from 15 to

. 60 minutes. Game wardens were asked to describe things such as the social class of poachers, the most difficult type of poacher to apprehend, the best part of the job of being a game warden, the extent of poaching in their area, and the extent to which they had been verbally and/or physically assaulted on the job. As with previous research endeavors on game wardens, these questions were intended to be "guides to discussion rather than generators of specific responses" (Forsyth 1994:50). This approach permitted pertinent information to be gleaned from their responses. All of the game wardens were male, and they ranged in age from 28 to 63 years old. The educational attainment of wardens in the study ranged from high school graduates to those who had Master's degrees. These individuals had experience as game wardens that ranged from 2 to 33 years.

\section{FINDINGS AND DISCUSSION}

\section{Youth Violations}

The majority of game wardens in this study indicated that they had broken various wildlife laws while growing up. They were asked: "When you were growing up, did you ever hunt or fish illegally? If yes, describe." Many of the violations committed by wardens as youths were deliberate violations of the law. Not all of them indicated they violated the law intentionally, however. Some indicated they did it because they didn't know any better or didn't know the law, while others said they did it because of Peer Pressure. Violations were thus categorized as Intentional, Ignorance, or Youth/peer pressure.

\section{Intentional}

Intentional offenses committed by game wardens, in their youth ranged from relatively.minor infractions such as license violations to more serious offenses such as killing deer out of season: Many were quite frank about their misdeeds and were willing to elaborate about the extent of their involvement in these types of illegal activities. For example, one warden with 20 years of experience stated the following:

Hunted out of season one time. Looked for the game warden the whole time.

An older warden with more than 30 years of experience admitted to committing an extensive number of violations as a youth:

Yes. I've probably violated most game laws, some intently [SIC] some by not knowing the law. My father was not a hunter or fisherman, didn't start till he was in his 50s. I was a loner, my friends also didn't hunt or fish. I could have used a role model. Examples, no junior license. Out of season rabbit, deer. Fishing, size limit, creel limit, shooting bass, over limit frogs. Shooting hawks, owls;' buzzards.

As the following comments indicate, other wardens admitted varying degrees of intentional involvement in wildlife offenses:

Yes! The river I grew up near is and was then under what is known as the Wild River Act. It is illegal to gig, snag or shoot 
fish in this river. 1 have done all these violations before the age of 16 . I never hunted illegally.

Yes..As a-boy-l-would take over the limit of.fish.-

When I was about six I tried to snag a catish from a bridge.

Yes. License violations in my mid and late teens.

Yes. I have killed over the limit of deer.

Raccoon hunting out of season. Shot ground hogs from vehicles whilie driving along roadways.

Yes. Fish and hunt. Sein fish. Shoot foxes at night by lights and have a deer or two.

Yes. [I] sometimes squirrel hunted during the November firearms season because there wasn't any deer near my home, thus no deer hunters.

\section{Ignorance}

Some of the wardens who had broken wildlife laws indicated that they had done so out of ignorance or because of lack of knowledge concerning the hunting and/or fishing regulations. For example, one warden in his forties claimed that his violations were due to a lack of knowledge regarding licensing requirements; seäsons, and bag limits:

Yes. But I did not know that a license was required and/or did not know that there were only certain sexes that you could .. - possibly harvest. I did not know there was such a thing as

$\because$ rabbit season or that there were limits on fishes. I only caught bluegill or mud catfish and I was content. I didn't know that I needed a license or that there were seasons until I graduated from high school.

The following comments from other wardens suggest that ignorance of the law was the primary reason for their misbehavior:

Yes, but only out of igniorance of the law. As a young person 'twielve and unider) I'didn't' even know there was a limit on squirrels. I have never conscièntiously [SIC] violated a fish and game law,

Not knowingly.

Not knowingly. Who knows what the regulations were back then.

Probably as a juvenile, simply by not knowing any better.

1 may have fished without a license while 16 or 17 years old I'm really not sure. It would only have been a couple of times. My father was VERY "by the book" on us keeping the fish and game laws.

\section{Youth/Peer Pressure}

A couple of wardens attributed their prior misbehavior to the effects of being a youth and the peer pressure that is common when a person is in the early stages of life. For example, one middle-aged warden with nearly 20 years of experience attributed his youthful misbehavior to a phase that most youth go through and are able to successfully resolve:

Yes. This appears to be a phase that most go through but some never grow out of it.

The comments of another individual, a young warden in his twenties, indicate that peer pressure was the driving force that influenced him to violate wildlife laws on a couple of occasions in his youth:

I trespassed one time when I was fifteen to kill some quail I had seen while riding around with some friends. Around the same time I shot a buzzard with a .22 rifle. This activity was a prime example of how you are affected by your peers. Other than that I was extremely straight laced.

\section{DISCRETION}

There was a definite connection between prior wildlife violations by game wardens and the use of discretion. All of the wardens except for one who violated the law as a youth used discretion when dealing with violators (20 out of 21$)$. On the 
other hand, only 75 percent ( 6 out of 8 ) of the wardenswho had not violated wildlife laws said that they used discretion. There was also some direct support for the aforementioned axiom "to catch a thief, set a thief." One warden inuts thirties stated the following in this regard:

Yes. I have violated some wildlife laws when I was younger and have been caught before. That's how I know what to look for.

In order to ascertain whether they used discretion, game wardens were asked if they used discretion with violators and if so to describe it. There were very few wardens in the study who didn't use discretion (3 out of 29). These indivi duals felt that their job was to treat everyone equally who had broken the law, as the following comment from one of those wardens, a 50 year old, suggests:

No, if they violate the law they will be cited and the court system makes the decision. My job is to enforce the law, not be judge and jury.

$\because \div$

Discretion was used by the majority of the game wardens in the study. The following general comments from some of the wardens illustrate the importance they place on possessing the capacity' to exercise discretion as they go about: performing their law enforcement duties:

$\therefore \quad$ Yes. Without it a law enforcement officer cannot survive.

Yes. Use of common sense.

Yes, this depends on many factors. i.e., type of violation, age of violator, mental state of violator, economic status of violator, and many more things that occur.

Sometimes. Husband and wife fishing out of season, [i] might cite just one of them.

To a degree. There are minimum and maximums to laws and depending on the circumstance the law works on minimums and maximums.

All the time. [I] take each case and always take time to talk to them.
The following statement by an officer in his thirties with a dozen years of experience on the job suggests that citing induriduals for each and every violation of the law can 7. actually be counterproductive to the agency's goal of achieving compliance with the law. He related how the use ofdiscretion is necessary for wildlife law enforcement to be Ceffective in the long run:

3x:

Yes. You have to use discretion with violators for a number of reasons. You want to curtail illegal activity, but at the same fime you have to realize you can't "nickel and dime" the public to the point where [we] lose credibility and public support. Sometimes you achieve longer lasting results with a verbal, or written warning, depending upon the nature of the violation, age and education of the offender, and his attitude.

The following comment from a young officer with a half dozen years of experience succinctly describes how he bases his decision to use discretion on the extent to which he perceives it will contribute to the achievement of his primary objective, which is to preventing future violations from occurring:

Of course, you always use officer discretion. One thing you never want to do is let your personal opinions of certain laws interfere with your judgment. I must look at the overall picture. My goal is to punish violators and sometimes set an example but most of all it is to stop any further violations from occurring. Whether a ticket, warning or just a good talking to will achieve this goal is usually where I base my decision to cite.

A comment by a middle-aged warden who was a seasoned veteran with nearly 20 years of experience on the job seemed to imply that younger officers who are new to the job tend to be harsh on violators, but as they get older and.more experienced they often stress the importance of enforcing the spirit of the law as opposed to the letter of the law:

Yes. A wise judge once told me that when you are a young officer you can use the "letter of the law," then as you mature as an officer you will learn the "spirit of the law." I use discretion and attempt to enforce the spirit of the law. 


\section{Seriousness of the Offense}

Consistent with previous research, one factor that was associated with the use of discretion was seriousness of the offense. In general, the more serious the offense the more likely it was that the officers would not.exercise discretion_in those situations and the violators would receive a citation. This is illustrated by the following comment of a warden in his forties that deals with a couple of hypothetical, yet common, situations that may be encountered by wardens in the field:

A lot depends on the violation. An example might be: 1) A man or woman taking his [or her] child fishing. He forgets to buy a license, I don't think he deserves a citation. 2) A man or woman take their child turkey hunting. They are hunting over bait. I think they deserve to be prosecuted to the fullest.

Another warden took licensing violations very seriously and had the following to say in regard to the seriousness of the offense:

Yes. I look to the intent of the person violating. However some violations such as hunting or fishing without a license always are issued a citation regardless of any mitigating circumstances. If the judge wants to turn them loose that's his business.

In general, those apprehended for minor violations were much more likely than others to be treated leniently. In many cases this took the form of giving warnings and courtesy notices to violators who had committed minor violations. In other situations, some wardens - reported being lenient by issuing a ticket for a single offense when multiple offenses were actually committed, and could have each been "stacked up $^{\prime \prime}$ against the offender. This is illustrated by the following statements from wardens:

Always. With the blessing of my courts. If I think my judge would dismiss a citation, 1 usually issue courtesy notices. If I cite someone to court the judge knows I feel it is a serious violation.
Yes. When possible for simple violations and mistakes 1 issue a courtesy notice instead of a citation. Inform and educate. After all we want compliance with the laws and regulations.

Yes. If I have various charges, unless they are serious charges, sometimes I will give a citation for $1-2^{-}$charges and written notices (courtesy notices) on the rest. That is a case by case situation.

There are degrees of violation. The older I got the more lenient I got.

These statements suggest that in most cases, individuals who commit serious offenses will be officially processed. Officers were most likely to be lenient in cases involving relatively minor instances of lawbreaking. These findings are consistent with the work of Gibbons (1972:183), who states that "selective and differential enforcement is likely to occur most frequently in the instance of minor lawbreaking."

\section{Prior Contact/Reputation}

Some wardens said that if an individual had a reputation for violating wildlife laws, it did not negatively influence their attitude toward those violators. They indicated that they tried not to take the actions of violators personally, and simply tried to be fair and do their job effectively. This type of attitude is evident in the following comments made by game wardens:

It used to. I finally realized that it is not a personal thing.

No. I have to catch that person in violation first before I make up my mind.

No. To violate the Fish and Game laws does not make you a bad person.

No, I try not to take the job personal.

No. I simply do my job.

No. They usually have the attitude change toward the officer (me). 
Not at all because I try each time they are caught [to] get through to them ... how stupid they are.

However, other wardens indicated that individuals who had reputations of being habitual violators due to prior contacts with the officers for wildlife violations were more likely to be closely scrutinized and viewed in a negative manner. The responses of wardens to the question "If someone comes to be known as a habitual wildlife law violator or "poacher," does it affect your attitude toward them? If yes, describe," can be classified into three categories: Need to be observed, The violator is a criminal/thief, and disrespecting the officer.

\section{Need to be Observed}

Some of the wardens felt that they needed to pay close attention to those individuals who had a history and reputation of violating the law. This is illustrated by the following comments of wardens. For example, one warden in his thirties claimed that offenders have a tendency to engage in the same activities over and over again, and stated the following in this regard:

In a way. I don't treat them any differently than I do anyone else, but I do pay attention to where I see them and when I see them. Violators, whether they know it or not, will operate in the same manner time after time (m.o.). When you see that, you know the person you saw may be working that area.

Another warden in his forties with more than 20 years of experience said that he had only dealt with a few repeat offenders, and added that they received harsh treatment from the judiciary when they went to court:

Yes. I will direct my attention in their areas more often. I have had less than a dozen repeat offenders but I have caught a few of them two or three times but when they went to court the second time they ended up paying for it severely!

The comments of other wardens indicated that they would take a greater interest in the activities of these individuals because of their prior activities and reputation:

No. Each case is unique. 1 do, of course, tend to observe for violations more intently.
Yes, I would observe that person more often.

Yes. If I know of past violations then I will look extra hard when $I$ run into this person. This is not personal feelings but just common sense.

Yes. I'm more cautious and curious concerning their activities.

Other wardens said that they would not mistreat offenders or violate their rights, but indicated that they would watch these individuals more closely since they had a history or reputation of engaging in wildlife offenses:

I would say yes because that person needs more watching. This does not mean I would mistreat them but I would watch them more closely in the woods.

Yes! In that I would probably watch them more closely and be less likely to believe them. However we are not prosecutors or judges. When a particular case is over, it is over!

Yes. You work harder to keep up with their daily and nightly activities and you make it a point to learn about them and their friends. They may not be bad people but you still make it a point to check them more closely when you encounter them.

Yes. My attitude towards them changes in that their actions dictate that I need to keep a watchful eye on them. My attitude towards them remains the same as far as respecting them and their civil rights. I do not hold a "grudge" toward them, and I think they all know that.

\section{The Violator is a Criminal/Thief}

Other wardens had a very low regard for habitual violators and equated them with common criminals and thieves. As such, they viewed these individuals in a very negative manner and were not likely to cut these violators any slack. These officers had negative attitudes toward violators that were similar to those that the "booker" types of wardens had toward poachers in Forsyth's (1994) study of game wardens in Louisiana. The following statement from a warden with 
18 years of experience revealed a no-nonsense, "get tough" stance toward habitual offenders:

Yes. A chronic violator does not get any benefit of the doubt. I recommend the maximum penalty the law allows for. However, if they are friendly I am friendly but still, no breaks.

Another warden in his fifties held a dim view of poachers and said that the activities of these individuals amount to thievery from the general public:

I lose respect for them. Because now they're a thief, and they're stealing from you and I. Also [from the] rest of [ali] legal hunters and fishermen.

Comments from other wardens indicated that they developed a dislike for violators that was manifest by a lack of respect as well as feelings of disdain toward these individuals:

Yes, [I] learn to dislike anyone who poaches all the time.

Yes. I have no respect for them in any way.

I don't care anything about being around them. I look at these people the same as I would any other thief.

\section{Disrespecting the Officer}

A couple of wardens in the study took the actions of habitual poachers personally, and believed that the misbehavior of these individuals represented a personal affront to them because of their status and authority as a law enforcement officer. They felt that by violating the law, these individuals were disrespecting their position of authority. For example, a warden in his thirties said the following about how he took the actions of poachers personally:

Yes. There is a severe personality clash between us. They go against everything ! believe in. They are essentially stealing from all the honest sportsmen in the state and the department who has worked so hard to establish the modern day populations of game that we have today. Our wives and families spend many nights and long hours without us at home due to people like this. When encountered in the field, someone who is known to be a "poacher" can expect to be looked at through a microscope.

Another young warden, in his twenties, indicated that he was very circumspect about his negative attitude toward habitual violators, and added that he received a great deal of satisfaction from successfully apprehending these individuals:

Certainly. Since there is usually just one conservation officer in each county it is very easy to take a habitual poacher's actions personally. Not only are they disrespecting the wildife resource but my position also. This attitude is never made public but eventually these people will screw up and get caught. This just adds a little more satisfaction to making a good arrest. I try to never set my sights solely on one poacher for very long. That will drive you crazy. Usually if you leave them alone they will screw up and get caught.

Another warden in his forties indicated that these individuals are dishonest and as such, he loses trust in them:

Yes. I tend to lose trust in them, knowing that they have and will lie to me. I tend to be more suspicious whenever I encounter them, and tend to check/or inspect them more thoroughly.

\section{Intent}

One significant factor that was found to be associated with the use of discretion for game wardens had to do with the intent of the violator. The following comments from wardens suggest that if the officers believed that an offense was a genuine, honest mistake they were much more likely to be lenient on the violator than if they believed the offense was a deliberate, intentional violation of the law.

The following comment is from an officer in his forties with nearly 20 years of experience. He described how he takes the intent of the violator into account when deciding whether to charge someone:

Yes. Whenever I feel that someone has violated the law through ignorance, I generally combine two or more charges into one, or give them longer to appear for arraignment. If I feel they have violated intentionally, I write each and every charge, and give them the minimum time for arraignment. 
A comment from a warden in his fifties suggests that individuals who commit certain types of offenses, especially serious, intentional ones, do not deserve any leniency whatsoever, and should be formally processed in the legal system:

You have discretion in the field. You can give a courtesy notice. A guy who is spotlighting at night, that guy needs to go to court.

The following comments from wardens indicate that offenses that are the result of an honest mistake or ignorance are often treated in a lenient manner, and suggest that discretion is an important tool for wildlife law enforcement to deal with these kinds of situations:

[I've used discretion] many times with seniors and genuinely sincerely honest mistakes. People who thought they were correct, but had an undersize fish or one fish over [the] limit (miscounted). Didn't know to make their own tags before hunting etc.

Yes. Not all violations are the same. They may brake the same law, however some are accidents while some are trying to get away with it.

Yes. Some people may not be aware of sizes, limits, etc. Any law enforcement without discretion is useless.

Yes. Sometimes a warning citation may be in order as to inform rather than to punish.

\section{Age}

In terms of age, discretion was most likely to be used with violators who were very young as well as those who were elderly. This was generally due to the fact that wardens believed that many of the individuals in these, categories are not as familiar with the rules and regulations as others and as a result are less likely to possess a complete, thorough understanding of the law and should therefore be treated leniently when they commit an infraction. This is exemplified by the following comment from a warden in his mid-thirties, who described how he uses discretion with the elderly and juveniles:
Yes, I once check[ed] an older adult who had a senior disable[d] card but not a license, he said he thought it was all he had to have so I gave him a warning and advised him of the law. Juvenile offenders I usually give the minimum fine to. if feel they need to know there is punishment for violating game laws.

The following comments from other wardens further illustrate the role that age plays in their decisions of whether or not to cite someone for an offense:

Yes. Sometimes if I find an older individual who has done little fishing and possibly has an $11 \frac{1}{2}$ large mouth bass, I'll explain to them the concept behind the law and return the fish to the water. I've also found some older folks who have no license but think they are still under the old blanket that after they turn 65 they need not have a license.

I try to use common sense when issuing citations. Juvenile hunters and fishermen usually get the second chance, and I talk with their parents, explaining the do's, don'ts, why not.

I use discretion when dealing with age, and mental cases.

Yes. I listen to whatever excuse they want to give. I also take into fact age of violator, if children are present. Whether our information given out from Frankfort is understandable, attitude, repeat offender.

\section{Gender}

Game wardens were more likely to be lenient with females who had violated the law than with males. Females have not traditionally participated in hunting and fishing activities to the same extent as men (Stedman and Heberlein 2001), so some wardens may go easier on them since they feel that they are inexperienced and as a result, not as apt to be familiar. with the laws and regulations that govern these types of activities. For example, a warden in his mid-thirties with a little over a dozen years of experience provided some examples of how he uses discretion based on the sex of the offender:

Yes. Example-husband and wife without a fishing license[i] only cite one. Example-mother and children fishing, [the]

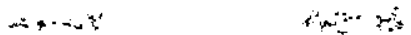


mother doesn't have a license-[I] may issue [a] courtesy notice.

\section{Attitude}

The attitude of a wild life law violator also played a role in one officer's decision to cite or not cite a violator for an offense. In the following comment, this particular officer, who was in his thirties, bluntly told of how he "throws the book" at violators who are dishonest in their dealings with him:

Yes! The violators attitude plays a role in the way I handle them. If they lie to me I use every means provided by my agency to encourage them not to lie to me again.

\section{CONCLUSION}

This research suggests the possibility that certain factors play an important role in the use of discretion by wildlife law enforcement personnel. Law enforcement officers have the ability to discriminate in terms of how they dispose of law infractions they encounter. They can be harsh on individuals and throw the book at them, or they can go easy on violators and cut them some slack. Consistent with prior research, factors such as seriousness of the offense as well as prior contact and reputation as a violator each played a major role in terms of whether or not discretion would be exercised by the officer. Wardens were more likely to go easy on offenders whose infractions were minor as well as those who did not have reputations as habitual violators. Intent of the violator was also found to be an important factor associated with the use of discretion. Wardens were much tougher on those individuals who committed deliberate, flagrant violations of the law than they were on those who committed honest mistakes or who committed their offense out of ignorance.

The job of game warden is a frequently overlooked occupation in today's society. These individuals àre responsible for protecting the nation's wildlife resources for future generations to enjoy. There is a critical need for additional research that examines the human dimensions of wildlife.

Prior research suggests that as the motivations for poaching change, discretion will play a more limited role in, the disposition of individual cases. That is, game wardens have sometimes gone easy on individuals who poach because they need the meat, and have even looked the other way and ignored some of those offenses (Forsyth et al. 1998). Nowadays, a greater amount of poaching is done for the thrill or excitement of it as well as the profit that can be_derived from it (Brymer 1991; Curcione 1992; Musgrave, Parker, and Wolok 1993). Forsyth et al. (1998:36) state: "With a greater percentage of younger poachers falling into the money or excitement categories, we also should see a decline in the differential enforcement by game wardens and the increasing criminalization of poaching in general."

There is a considerable amount of social change occurring in society that has the potential to significantly impact traditional uses of wildlife via changes in hunting laws (Heberlein 1991). These changes include urbanization and sprawl that is occurring at an alarming rate and which results in additional areas being classified as off limits to hunting. The activities of various animal rights organizations are significant as well, since the primary objectives of many of these groups include the elimination of sport hunting and trapping. Hunting has been criticized for being violent (Kheel 1996), and is increasingly being viewed by many individuals in mainstream society as an antisocial act (Heberlein 1991).

Change also is occurring with respect to the trend toward the increasing commercialization of wildlife. It is exemplified by the increasing popularity of guided and fee hunting on private property, especially in the western region of the United States. It is possible that this also may contribute to the increased criminalization of poaching in the future. As wildlife becomes a valued commodity for those who can derive a substantial economic profit from it on their land via guided hunts, we should see strict laws emerge that are designed to protect the resource. For example, McGrath - (1992) reported that poaching became an issue for the government in Newfoundland and Labrador in 1982 when it wanted to expand the tourist industry via big game hunting by non-residents.

The role that personal experience plays in influencing the use of discretion should be elaborated upon in future studies. For example, in addition to examining violation of wildlife laws as a youth and its impact on the use of discretion, research should be directed toward the study of lawbreaking 
behavior in general and its association with the use of discretion. It would be useful to know the extent to which the violation of any laws as a youth (e.g., stealing, vandalism, alcohol or drug violations, etc.) influence discretionary decision making on the part of game wardens as well as other police officers in general.

Future research should also examine the role that departmental organization plays in the use of discretion by wildlife law enforcement officers. It would be informative to ascertain the degree to which departmental policies have a bearing on individual decision making by officers. For example, do some departments have "zero-tolerance" policies for certain offenses? These and other questions need to be addressed by scholars in the future.

\section{REFERENCES}

Bachman, Ronet. 1992. "Crime in Nonmetropolitan America: A National Accounting of Trends, Incidence Rates, and Idiosyncratic Vulnerabilities." Rural Sociology 57:546-60.

Baird, Dale. 1983. "An Idaho Tragedy-What Can We Learn." Proceedings of the Western Association of Fish and Wildlife Agencies 63:65-68.

Barker, Thomas and David A. Carter. 1986. Police Deviance. Cincinnati: Anderson.

Barker, Tom and David Carter. 1990. "Fluffing Up the Evidence and Covering Your Ass: Some Conceptual Notes on Police Lying." Deviant Behavior 11:61-73.

Bartollas, Clemens and Stuart J. Miller. 2001. Juvenile Justice in America, 3 rd ed. Upper Saddle River, NJ: Prentice Hall.

Becker, Howard. 1963. Outsiders. New York: The Free Press.

Black, Donald and Albert Reiss. 1970. "Police Control of Juveniles." American Sociological Review 35:63-77.

Brown, Michael K. 1981. Working the Street: Police Discretion and the Dilemmas of Reform. New York: Russell Sage Foundation.

Bryant, Clifton D., Donald W. Shoemaker, James K.'Skipper, Jr., and William E. Snizek, Editors. 1985. The Rural Workforce: NonAgricultural Occupations in America. South Hadley, MA: Bergin \& Harvey.

Brymer, Richard A. 1991. "The Emergence and Maintenance of a Deviant Sub-Culture: The Case of Hunting/Poaching Subculture." Anthropologica 33:177-94.

Cicourel, Aaron. 1976. The Social Organization of Juvenile Justice. New York: Wiley.
Coleman, James W. 1994. The Criminal Elite: The Sociology of WhiteCollar Crime. New York: St. Martin's.

Curcione, Nicholas R. 1992. "Deviance as Delight: Party-Boat Poaching in Southern California." Deviant Behavior 13:33-57.

Denzin, Norman K. 1989. Interpretive Interactionism. Newbury Park, CA: Sage.

- 1970. The Research Act. Chicago: Aldine.

Dillman, Don A. 1978. Mail and Telephone Surveys: The Total Design Method. New York: John Wiley \& Sons.

Eliason, Stephen L. 1999. "The Illegal Taking of Wildlife: Toward a Theoretical Understanding of Poaching." Human Dimensions of Wildlife 4:27-39.

Eliason, Stephen L. and Richard A. Dodder. 1999. "Techniques of Neutralization used by Deer Poachers in the Western United States: A Research Note." Deviant Behavior 20:233-52.

Forsyth, Craig J. 1993a. "Chasing and Catching "Bad Guys": The Game Warden's Prey." Deviant Behavior 14:209-26.

1993b. "Factors Influencing Game Wardens in Their Interaction With Poachers: The Use of Discretion." Free Inquiry in Creative Sociology 21:51-56.

1994. "Bookers and Peacemakers: Types of Game Wardens." Sociological Spectrum 14:47-63.

Forsyth, Craig J., Robert Gramling, and George Wooddell. 1998. "The Game of Poaching: Folk Crimes in Southwest Louisiana." Society \& Natural Resources 11:25-38.

Forsyth, Craig J. and Neal Shover. 1986. "No Rest for the Weary ... Constructing a Problem of Elderly Crime." Sociological Focus 19:375-86.

Gibbons, Don C. 1972. "Crime in the Hinterland." Criminology 10:177-91.

Heberlein, Thomas A. 1991. "Changing Attitudes and Funding for Wildlife-Creserving the Sport Hunter." Wildlife Society Bulletin 19:528-34.

Hummel, Richard L. 1983. "Hunting and Fishing-But Not in Sociology." The Rural Sociologist 3:255-58.

Kheel, Marti. 1996. "The Killing Game: An Ecofeminist Critique of Hunting." Journal of the Philosophy of Sport 23:30-44.

Kirby, Chester. 1933. "The English Game Law System." American Historical Review XXXVIII:240-62.

Long, Jeffery B. 1985. Outlaw: The True Story of Claude Dallas. New York: William Morrow and Co.

McGrath, Darrin M. 1992. Poaching in Newfoundland and Labrador: The Creation of an Issue. Unpublished Master's thesis, Memorial University of Newfoundland, Canada.

Munsche, P. B. 1981. "The Gamekeeper and English Rural Society, 1660-1830." Journal of British Studies 20:82-105. 
Musgrave, Ruth S., Sara Parker, and Miriam Wolok. 1993. "The Status of Poaching in the United States: Are We Protecting Our Wildlife?" Natural Resources Journal 33:977-1014.

Muth, Robert M. 1998. "The Persistence of Poaching in Advanced Industrial Society: Meanings and Motivations-An Introductory Comment." Society \& Natural Resources 11:5-7.

Muth, Robert M. and John F. Bowe-1998. "Illegal Harvest of Renewable Natural Resources in North America: Toward a Typology of the Motivations for Poaching." Society \& Natural Resources 11:9-24.

Palmer, C. Eddie and Clifton D. Bryant. 1985. "Keeper's of the King's Deer: Game Warden's and the Enforcement of Fish and Wildlife Law." Pp. 111-37 in The Rural Workforce: Non-Agricultural Occupations in America, edited by Clifton D. Bryant, Donald W. Shoemaker, James K. Skipper, Jr., and William E. Snizek. South Hadley, MA: Bergin \& Harvey.

Pepinsky, Harold 'E. 1976. "Police Patrolmen's Offense-Reporting Behavior." Journal of Research in Crime and Delinquency 13:33-47.

Pfohl, Stephen. 1994. Images of Deviance and Social Control: $A$ Sociological History. New York: McGraw-Hill.

Piliavin, Irving and Scott Briar. 1964. "Police Encounters with Juveniles." American Journal of Sociology 70:206-14.

Regoli, Robert M. and John D. Hewitt. 2000. Delinquency in Society. Boston: McGraw-Hill.

Ross, H. L. 1961. "Traffic Law Violation: A Folk Crime." Social Problems 9:231-41.

Skolnick, Jerome H. 1975. Justice Without Trial. New York: Wiley.

Smith, Douglas A. and Christy A. Visher. 1981. "Street-Level Justice: Situational Determinants of Police Arrest Decisions." Social Problems 29:167-77.

Stedman, Richard C. and Thomas A. Heberlein. 2001. "Hunting and Rural Socialization: Contingent Effects of the Rural Setting on Hunting Participation." Rural Sociology 66:599-617.

Stockdale, Michael. 1993. "English and American Wildlife Law: Lessons From the Past." Proceedings of the Annual Conference of the Southeastern Association of Fish and Wildlife Agencies 47:732-30.

Terry, Robert. 1967. "Discrimination in the Handling of Juvenile Offenders by Social-Control Agencies." Journal of Research in Crime and Delinquency 4:218-30.

Vago, Steven. 2000. Law and Society. Upper Saddle River, NJ: Prentice Hall.

Walsh, William F. and Edwin J. Donovan. 1984. "Job Stress in Conservation Officers." Journal of Police Science and Administration 12:333-38.

Weisheit, Ralph A. and L. Edward Wells. 1996. "Rural Crime and Justice: Implications for Theory and Research." Crime and Delinquency 42:379-97.

\section{religiosity and perceptions of crime seriousness by jewish and muslim respondents in israel}

\author{
Sergio Herzog \\ University of Haifa, Haifa, Israel
}

Most empirical research has attempted to demonstrate the relationship between religiosity and criminal behavior principally on the basis of self-reported measures of criminality. The present study analyzed the influence of individual religiosity on personal perceptions of the seriousness of a variety of criminal offenses. Findings obtained from a national sample of. Israeli respondents with varying degrees of religiosity and belonging to two different religions-Judaism and Islamsupport the existence of effects of religiosity on perceptions of crime seriousness. Moreover, in the case of the Jewish respondents, religiosity emerged as the variable exerting the most influence on their perceptions of victimless offenses.

\section{INTRODUCTION}

The relationship between religiosity and crime has been a topic of research for social scientists and religious practitioners for more than 40 years (Elifson et al. 1983). Generally, many sociological and criminological theories (e.g., of

Received 24 September 2001; accepted 2 May 2002.

Address correspondence to Sergio Herzog, Department of Sociology and Anthropology, University of Haifa, Haifa 31905 Israel. E-mail: sherzog@soc.haifa.ac.il 